\title{
Education of Muhammadans and Role of Press during First Half of 20thcentury In Bihar
}

\author{
Mehnaz Ara \\ (History, Aligarh Muslim University, Aligarh)
}

\begin{abstract}
India is a land of diversity, a mosaic of many caste, communities, languages, religion and cultures. In British India the credit for the first step towards education in Muhammadans goes to Warren Hasting who founded a Madrasa in Culcutta in 1781 to promote and encourage the study of Arabic, Persian and Urdu languages. Until the first half of the $20^{\text {th }}$ century education in India amongst Muslims was imparted through the institutions of traditional learning like maktabs and madrasas where fundamental or elementary education was imparted. The present paper attempt to seek the development and progress of education amongst Muhammadan and tried to explore the role of press in the field of educating the people through disseminating information on various aspects. The paper mainly focused on the vernacular newspapers of Bihar where these newspapers not only ventilate the community's grievances but it also appealed to the authorities to set apart funds for maktabs in every districts because it believed that Muhammadans suffered under various handicaps as result of their being in minority in the circle panchayat and local bodies. The Press also criticized the government for not doing enough for Muslim education.
\end{abstract}

Key words: British Policy, Education, Maktab and Madrasas, Muhammadans, Vernacular Newspapers

The Holy Prophet (S.A.W.) has said: "Atta libul ilm faridhatol kuli muslim." This Hadith means: "Attainment of knowledge is a must for every Muslim." The other Hadith quotes "Seek Knowledge from the cradle to the grave."The Qur'an is full of exhortations to pursue knowledge (e.g. Q. 20:114); it proclaims the superiority in God's eyes of those who have knowledge (e.g. Q. 58:11 and 39:9), but also emphasizes wisdom and guidance rather than the blind acceptance of tradition (Q. 2: 170, 17:36 and 6:148). The pursuit of knowledge, it seems, is a religious duty. ${ }^{1}$

In India the history of education of Muhammadans affected with the advent of Muslim rulers. The institution of higher learning was Madrasas, founded by Sultans, nobles and their influential ladies. The main objective of this education was to train such ulema or scholar who would become eligible for the civil service as well as performing duties as judge or qadhi."Madrasa is an institution of learning, where Islamic sciences including literary and philosophic ones are taught." ${ }^{2}$ Avowed aim of madrasa education is to inculcate the belief and practice of Islam among its followers and guide them to follow Quran and traditions of the Prophet. The foundation of Madrasa education is therefore, basically standing on two pillars of Quran (Collection of God's revelations to Prophet Mohammad) and Sunna (Tradition of Prophet Mohammad).The history of madrasa, dates back to the establishment of Delhi Sultanate in 1206 A.D. Initially its principal function was to train personnel for government service (Encyclopedia of Islam) and accordingly curriculum was formulated to cater the administrative needs of Muslim rulers. Gradually with the patronage of these rulers it was extended to different parts of north India. The claim of some Muslim thinkers that religious, rational and natural sciences were also introduced in the curriculum of madrasa in India to meet the educational need of the time appears to be a myth. "Science flourished in the Golden Age of Islam because there was within Islam strong rationalist tradition, carried out by a group of Muslim thinkers known as Mutazilites." ${ }^{3}$

During Muslim rule in medieval ages these madrasas were centers of higher knowledge and provided religious as well as then available scientific knowledge known as 'ulum-i- 'aqliyah (intellectual knowledge). These centers of learning were naturally patronized by the kings, nawabs and 'jagirdars' (feudal lords). Thus what is known as Dars-i- Nizamiyah synthesised both religious and natural sciences of the time. However, with the decline of the Mughal rule and establishment of British rule these centers of higher knowledge fast declined and were left with no resources to grow and imbibe the modern knowledge. Now small madrasas came into existence in different localities, which were run by donations from local communities and catered to elementary religious knowledge. ${ }^{4}$

In the initial years, however, the British needed to understand the existing law and culture of the country and for this they had to depend on the Hindu pundits and the Muslim Qazis for law and administration. Because of this and also because of pressure from a section of the community, Warren Hastings, as governorgeneral, established the Calcutta Madrasa (Alia Madrasa) in 1781 for the study of "Muhammadan law and such other sciences as were taught in Muhammadan schools". ${ }^{5}$ When the British took over the country, they 
introduced a secular type of education and replaced Persian with English. Thus the system of the madrassas received a damaging blow. In 1835, the Governor General Lord William Bentinck made the law that it was the prime obligation of the government to make better arrangements for the teaching of English and also issued a resolution that all the funds appropriated for the purpose of education would be best employed on the English education alone. Subsequently, Lord Macaulay, the first Law Member of the Governor-General's Council in India, stressed the British Government to establish education system that can secure the interests of the British. ${ }^{6}$

British educational policies were regarded by Muslim leaders as a threat to the integrity of their religion and culture. English education was not seen by the Muslims as merely being a medium for the transference of knowledge but as a vehicle for the Christianization of Indian Muslims. Muslims, who were now behind the Hindus in terms of having an English education, also lost their traditional system of education as the Government confiscated tax-free lands. This measure was the result of the East India Company's financial difficulties with respect to shareholders' payments in England. To compensate for the shortfall the Company boosted its revenue by confiscating the tax-free lands on which many primary schools and the institutions of higher learning were situated. To stem this action, the legal deed-holders of these lands were obliged to submit proper documentation, which in most cases had either been lost or eaten by termites. In these circumstances, the Muslims intelligentsia realized that Muslims must reorganize their educational system and they must also acquire the modern education so that they may be at par with the other communalities in order to have an access to economic opportunities. ${ }^{7}$

With the disintegration of Muslim rule particularly after the advent of British, madrasa education gradually lost its shine it had during Muslim rule. It received a major setback and suffered further reversal with the introduction of modern education. Madrasa teachers therefore, became restive and developed a more rigid attitude towards religion-centric education for Muslims. The historic participation of madrasa leaders in 1857 revolt against British regime proved that the main objective of traditional Islamic education was to regulate the Indian Muslims with aspiration for regaining of political power. ${ }^{8}$ The revolt of 1857 , in which several Indian ulema are said to have played an important role, represented, in a sense, an effort on the part of the increasingly threatened ulema to defend their privileges. With the failure of the revolt, many ulema turned now to setting up a chain of madrassas, for it was felt that under alien rule Islam was under grave threat and that it was only by preserving and promoting Islamic knowledge that the younger generation of Muslims could be saved from sliding into apostasy and prevented from falling prey to the blandishments of the Christian missionaries. Because they perceived themselves under siege and saw Islam as under attack by the Christian British, the ulema seem to have adopted a deeply hostile attitude toward Western knowledge. The "educational jihad" that they now launched to preserve traditional Islamic learning was seen as taking the place of failed physical jihad against the British and as a working to train class of ulema who would take revenge on British for having overthrown the Mughals. ${ }^{9}$ After the failure of 1857revolt Muslim Ulama feared that the Muslim mode of life may get weak due to western education introduced by British. Their immediate need was to keep a check on the possibility of their community moving towards modern education and ensure to carry forward the Persho-Arab legacy, which was possible only through madrasa education. They launched madrasa movement by establishing an Islamic seminary known as Darul Uloom at Deoband in 1866 with a view to educate Indian Muslims with Islamic system of education. ${ }^{10}$

By the close of nineteenth century madrasas like Farangi Mahal (Lucknow), Dar-al-Ulum (Deoband) and Nadwat-al-Ulama (Lucknow) came into existence during a period of great crisis for north Indian Muslims when Muslims were facing British wrath and the 'ulema were in the forefront of anti-British struggle much before Indian National Congress came into existence and national freedom movement started. These 'ulema remained steadfast in their struggle for freedom and also became allies of the Congress and firmly opposed two nation theory and partition of the country. ${ }^{11}$ By the arrival of Lord Thomas Babington Macaulay in India as Viceroy of the British India Company, Macaulay is most quoted for saying: "We must at present do our best to form a class who may be interpreters between us and the millions whom we govern; a class of persons, Indian in blood and colour, but English in taste, in opinions, in morals, and in intellect." ${ }^{12}$ The implications of this statement were far reaching, going beyond just clerical curriculum in formal school during colonial rule. To the Ulema, this was seen as a move to reduce greatly the cultural and religious heritage of the Muslims and in an attempt to neutralize this threat, the Ulema's orthodoxy took radical shades. Madrasa in the early 20th Century were diverse in the subjects they offered and some even secular, allowing Hindu's to attend their classes. Raja Ram Mohan Roy, Dr.Rajendra Prasad and Dr. Sachdanand Sinha were all imparted elementary education at madrasas. But soon, the Ulema came to equate natural and social sciences with the same British Raj that wanted to destroy their religion. They became rigid and vehemently followed the Dars-e Nizami (curriculum). Mullah Nizam al-Din Muhammad Sihalwi (1677-1748), being the founder of this course, primarily aimed this course to comprise the study of religious sciences from step one to the highest levels of intellectual spheres. As part of the study of classical doctrine in Islamic theology, Hadith, Qura'n and their Principles, Jurisprudence and its principles, the students of this discipline pursued the liberal arts which offered a canonical method of depicting 
the realms of higher education. ${ }^{13}$ Sir Syed Ahmad Khan launched Aligarh movement and established Madrasatyl Ulum at Aligarh in 1873 for imparting education in modern branches of learning, which later became Mohammadan Anglo oriental college and then Aligarh Muslim University. Being more realistic he tried to inspire Muslim society towards modern education. With a view to fashioning the education policy exclusively for Indian Muslims, Sir Syed Ahmad formed All India Muslim educational Conference in 1886. It was in fact a part of Aligarh movement. Its basic aim was to fashion the education policy for Indian Muslims and encourage them towards the mainstream of western education. ${ }^{14}$

In Colonial India press was an effective instrument of the nationalist both in transmitting the message of freedom to the masses of India and raising the public consciousness against the colonial rule. ${ }^{15}$ The history of the Press in India is the history of struggle for freedom. The first newspaper in India, the Bengal Gazette or Calcutta General Advertiser was published in 1780 at Serampore by one James Augustus Hicky. ${ }^{16}$

The British Administration feared that popular awakening through indigenous press might be detrimental to their imperial interest so there were so many restrictions were on press. ${ }^{17}$ The province of Bihar was backward in this field also. ${ }^{18}$ Though, Bihar had been a great centre of learning in past but it could not adopt he modern western educational system in the early phase of the British rule. Adam's dispatch confirms the fact that there were no more than two centers of English education in Bihar till 1835, whereas Bengal possessed even a college for this purpose as early as $1816 .{ }^{19}$ The first Urdu Press in Bihar could be established as late as in 1850 at Sasaram by one kamrruddin Ahmad and the first Bihari paper Noor-ul-Anwar, could be initiated only in 1853 from Arrah. The Urdu Press took keen interests in scientific and literary pursuits. This aroused the consciousness of the hitherto sleeping educated class, though being a minority, to join the fray. The Urdu journals pioneer of Bihari journalism and maintained their monopoly for over a decade to come. There were some reasons for their early growth and first of all, Urdu in Persian character being the court language as well as the medium of instruction in most of the educational institutions of the time and it had privilege over other languages. ${ }^{20}$ Urdu papers were not lagging behind Hindi or English newspapers of the time in ventilating public grievances or demanding justice from the government and in spite of their backwardness and financial trouble, and some times, their support to the actions of the government, they wrote strong articles pleading for the just causes of the people. ${ }^{21}$ The vernacular press continued to take interest in the discussion of educational matters relating to the province. These papers professing different political views vied with one another in criticizing the educational policy and measures of government. ${ }^{22}$

Education is the most critical indicator of human development and a pre-requisite of socio- economic progress. ${ }^{23}$ From around 1870 the elites in Bihar started showing a new concern for the promotion of education. From 1871-72 to 1891-92 numbers of schools grew four times while those of students six times. By 1897 the increase was even greater. ${ }^{24}$ When viewed in terms of community participation, it becomes apparent that the Muslims showed greater response to the new education, a factor which was to prove crucial to the emergence of a joint Hindu-Muslim front in Bihar's search for a distinct identity. Thus, in 1869-70 in the higher schools, the Muslims formed 20.14 per cent of the pupils in the North-West Division and in the Middle Vernacular schools they formed 26.57 per cent of the pupils. Similarly, in 1872 out of 421 boys in Patna Collegiate Schools, 90 were Muslims. ${ }^{25}$ The percentage of Muslim pupils to the total number of pupils as compared to the percentage of their population to the total population remained much greater even in 1895-96 in the Patna Division. ${ }^{26}$ The impact of Lord Curzon's education policy was felt all over the country, including in Bihar. In 1904-05, a decision was taken to open 37 primary schools for girls in the larger province of Bengal, but only 6 out of these were established in the area comprising present Bihar. According to the first quinquennial review of the progress of education in Bihar and Orissa (1912-17), the government had taken over the responsibility of running vernacular middle, upper primary, lower primary and recognised Maktabs and Sanskrit Pathshalas. ${ }^{27}$ The press in Bihar played an important role in the field of educating the people through disseminating information on various aspects. ${ }^{28}$ The year 1917 was significant in the history of education in Bihar. For, it was during this year that the Patna University was established and the responsibility of conducting Board examinations for the secondary schools of Bihar was transferred from the Calcutta University to the newly established Patna University. ${ }^{29}$ The educational needs of the Province were fully emphasized in the press. The press commented on the backward state of education that was prevailed. The Behar Herald wrote:-"The recent annual report on the education in Bihar and Orissa is a mournful study. In a land which was once the eye of Bharatbarsha, a land from which knowledge flowed to China and Tibet, to-day 85 out of every hundred persons of school going age are receiving no sort of education at all, not even learning the bare alphabet in a maktab or the lowest form of Primary school. Three villages out of every four are without any school, good, bad or different." ${ }^{30}$ The establishment of the Ayurvedic Colleges was favourablly commented upon in the vernacular papers. The Urdu paper Ittehad in a series of articles commented on the personnel of a Tibbi College appointment. The paper also suggested in its issue through a correspondent that the Hon'ble Minister was promoted by personal consideration to support the candidature of some applicants who had either a third grade diploma or none at all. ${ }^{31}$ The Mithila Mihir contended that the country had nothing to expect from schools and colleges which 
merely manufactured "pleaders, mukhtars and clerks year after year. The paper further said that if the present system of education continued for long India will surely ruin in near future. ${ }^{32}$ The paper Narad condemned and attacked on the Government attitude towards the education. It said: - "Education has become expensive, there is no doubt about it, and that one cannot do without education is also clear; but then anything in the present system which tends to make the expenses prohibitive and at the same time stands in the way of efficiency and thoroughness should be depreciated and put down as early as possible." ${ }^{33}$ The Ittehad busied itself with the condemnation of Hindi book on history which it asserted was prescribed as a text-book for use in schools and which contained wrong and incorrect allegations against the Prophet of Islam. The Ittehad also criticized the government for the low payment of Arabic teachers appointed in madrasas, maktab and schools for Muslim. ${ }^{34}$ The Hon'ble Mr. justice Khwaja Muhammad nor was appointed as Vice-chancellor of the Patna University. The appointment was welcome by the Nadeem and the Ittehad, though the Ittehad expected that some non-official would be appointed as vice-Chancellor. A general dissatisfaction against western system of education was expressed in the columns of the Shiksha, the Shri Krishna and the Ittehad. The Shiksha reiterated its demand for making vernacular as the medium of instruction in schools. The Urdu newspaper the Nadeem urged specially the appointment of a professor of Urdu by the Patna University. The Ittehad pleaded for better pay for Arabic teachers. The same paper also opened its columns to an unsigned attack against the District Inspector of Schools, Gaya and gravely asserted that it apprehended injury to the interest of the Muhammadans under the Minister's term of office. ${ }^{35}$ The Shiksha was one of the important educational magazines and continued to make suggestions for the educational reform. The question of adopting vernacular as medium of instruction in High Schools was discussed more than once and the cause of female education was often pressed. The Nadeem pleaded the adoption of Urdu in M.A classes and the Ittehad and the Imarat objected to certain text books of history on the ground that they excited hatred against the Muhammadans. ${ }^{36}$

The Urdu paper Ittehad, published from Patna issued a series of article on the ignorant of government towards Muhammadans education. A correspondent writing, the Ittehad complains that the teaching of the Arabic is being neglected in spite of the steps taken by the Government to open madrasas and introduce Arabic as an optional subject in the schools. It also point out that the payment of Arabic teachers is very low and the amount spent on it is very small in comparison respectively to what is paid to drill masters and ordinary artisans, and to what is spent on the construction and equipment of the scavengers' quarters. ${ }^{37}$ The Imarat greatly regretted that the education of Muhammadans Minister for nine continuous years. The paper further said that Muhammadans do not ask for anything more than what is due to them, but none of this should be given to the Hindus. The paper the Imarat and Al-Haque complained that the education of Muhammadan boys was not well looked after by the district boards in general and the Champaran Board in particular. The Ittehad accused the Headmaster of the Patna Training school of discouraging the use of Urdu. ${ }^{38}$ The Bihari dissatisfied with the comparatively small amount spent annually by the Bihar Government on education as compared with the expenditure of other provinces. It wrote:-"We do not know whom to blame, the Government of India or the Local Government. But this much is certain that the allotment of funds is hardly fair to the people of this Province." ${ }^{39}$ The paper Ittehad in its other issue pointed out certain grievances in the matter of appointments in the education services, it said that certain posts of Persian professors had been abolished and certain other posts which were reserved for Muhammadans had been given to non-Muhammadans. ${ }^{40}$ The Urdu newspaper believed that the cause of primary education among Muhammadans was being deliberately neglected. The Al-Mubasshir and Al-Haque joined in giving facts and figures to prove that disparity in the amounts spent on Hindi and Urdu primary schools. The Al-Haque said that it was pity that out of Rs. 50, 61,320, only 3, 19,579 was spent on the education of Muhammadan children. The same paper also complained of poor representation of Muhammadans in the Education services. The Urdu papers also complained against the Champaran district board that Gita was taught to Muhammadan boys in the schools managed by it. ${ }^{41}$

To conclude we see that in the modern times the press has been the chief source of the spread of education. A review of newspapers during the period of our study reveals great interest shown by the press in Bihar in the educational progress of the province. The establishment of the Patna university was landmark $\mathrm{n}$ the history of educational progress of Bihar. ${ }^{42}$ The Press in Bihar rightly deplored the neglect of the mother tongue as the medium of instruction and strongly pleaded for the expansion of primary and secondary education amongst Muhammadans.

\section{References}

$\left[{ }^{1}\right] \mathrm{J}$. Mark Halstead, An Islamic Concept of Education, Comparative Education, Vol. 40, No. 4, Special Issue (29): Philosophy, Education and Comparative Education (Nov., 2004), ( published by Taylor and Francis Ltd.)p. 520

$\left[{ }^{2}\right]$ Encyclopedia of Islam - Leiden E.J. Brill

$\left.{ }^{3}\right]$ Parvez Hoodbhoy quoted in 'The Secularist' in its issue no.191 September-October 2002

$\left[{ }^{4}\right]$ Asghar Ali Engineer, Muslim and Education, Economic and Political Weekly, Vol. 36, No. 34 (Aug. 25-31, 2001) 
$\left.{ }^{5}\right]$ Padmaja Nair, The State and Madrasas in India, Religions and Development Research Programme , 2009, p.12

$\left[{ }^{6}\right]$ Shazia Ramzan and Ainee Rabab, Madrasa Education in the Sub Continent-Myth and Realities, Al-Idah 27December, 2013,pp.36-37 $\left[{ }^{7}\right]$ ibid.,p.37

${ }^{8}$ ] R.Upadhyay, Madrasa Education in India- Is it to sustain medieval attitude among Muslim?, South Asia Analysis Group, 730,2014

${ }^{9}{ }^{3}$ Yoginder Sikand, Reforming the Indian Madrassas, Contemporary Muslim Voices, in Satu P. Limaye (Ed), Religious Radicalism and Security in South Asia (Asia-Pacific Center for Security Studies Honolulu, Hawaii, 2004), p.122

$\left[{ }^{10}\right] R$.Upadhyay, Madrasa Education in India- Is it to sustain medieval attitude among Muslim?, South Asia Analysis Group, 730,2014

$\left[{ }^{11}\right]$ Asghar Ali Engineer, Muslim and Education, Economic and Political Weekly, Vol. 36, No. 34 (Aug. 25-31, 2001),

$\left[{ }^{12}\right]$ Devana Soni, Muslim Education, A Study of Madrasa, CCS Researching Reality Internship 2010, p.10

$\left[{ }^{13}\right]$ Ibid

$\left[{ }^{14}\right]$ R.Upadhyay, Madrasa Education in India- Is it to sustain medieval attitude among Muslim?, South Asia Analysis Group, 730 , 2014

$\left.{ }^{15}\right]$ Sudhir Kumar Singh, Press, Politics and Public Opinion in Bihar, (New Delhi: Manak Publication 2010), pp.4-5

$\left[{ }^{16}\right]$ R.C.S. Sarkar, The Press in India, ( New Delhi 1984), p.17

$\left[{ }^{17}\right]$ Basanti Sinha, Press and National Movement in India (1911-1947) (New Delhi: Manak Publication) pp.1-2

$\left.{ }^{18}\right]$ Ibid, p. 1

$\left[{ }^{19}\right]$ Sudhir Kumar Singh., op.cit, p.13

${ }^{20}$ ]ibid, pp. 13-14

$\left[{ }^{21}\right]$ Ibid., p. 15

$\left.{ }^{22}\right]$ Basanti Sinha, op.cit., pp.89-90

$\left.{ }^{23}\right]$ Abdul Waheed, Muslim Baradaries, Occupation and Education, (New Delhi 2011), p.49

$\left[{ }^{24}\right]$ narendra Jha, The Making of Bihar and Biharis, Colonialism, Politics and Culture in Modern India c. 1870-1912 (New Delhi: Manohar 2012), pp. $70-75$

$\left[{ }^{25}\right]$ ibid., p. 80

$\left[{ }^{26}\right]$ ibid

$\left[{ }^{27}\right]$ Report of the common School System Commission submitted on 8 June, 2007, Government of Bihar, Patna. p. 6

$\left[{ }^{28}\right]$ Basanti Sinha, op.cit., p.85.

$\left.{ }^{29}\right]$ Report of the common School System Commission submitted on 8 June, 2007., Government of Bihar, Patna.p.7

$\left[{ }^{30}\right]$ Political Dept., Special Sec., File No-11/1916, p.9

$\left[{ }^{31}\right]$ Basanti Sinha, op.cit, p.86

${ }^{32}$ IIbid., p.90

$\left[{ }^{33}\right]$ Political Dept., Special Sec., Annual Report on Indian Newspapers and Periodicals published in Bihar and Orissa during the year 1924,, File No.17/1925

$\left[{ }^{34}\right]$ Annual Report on the Hindi and Urdu Newspapers and periodicals published in the province of Bihar and Orissa during the year 1932. File No-1/1930,p.30

$\left.{ }^{35}\right]$ Annual report on Newspapers published in Bihar and Orissa in 1933, file No. 1/1934

$\left[{ }^{36}\right]$ Political Dept., Special Sec., Annual Report on Indian Newspapers and Periodicals published in Bihar and Orissa during the year 1933,

File No. 1/1934, p.3

$\left[{ }^{37}\right]$ Political Dept., Special Sec., File No. 287/1932.

$\left[{ }^{38}\right]$ Annual Report on Indian Newspapers and Periodicals published in Bihar and Orissa during the year 1929, File No. 1/1930, pp.24-25

${ }^{39}$ ]Political Dept., Special Sec.,11/1916, p.9

$\left[{ }^{40}\right]$ Basanti Sinha., op.cit p.126

$\left[{ }^{41}\right]$ Political Dept., Special Sec., File No-1/1929

$\left[{ }^{42}\right]$ Basanti Sinha, op.cit., p. 134 